\title{
Effect of NPK and Bio-Fertilizers on Growth, Yield, Quality of China Aster (Callistephus chinensis) cv. Shashank for Cut Flower Production under Agro Climatic Conditions of Allahabad, India
}

\author{
K.A. Sowmya* and V.M. Prasad \\ Department of Horticulture, Naini Agricultural Institute, Sam Higginbottom University of \\ Agriculture, Technology and Sciences, Allahabad, U.P., India \\ *Corresponding author
}

\section{A B S T R A C T}

\section{Keywords}

China aster, cv. Shashank, NPK, Bio-fertilizers, DAT-days after transplanting.

\section{Article Info}

Accepted:

26 September 2017 Available Online: 10 October 2017
The Present investigation entitled "Effect of NPK and Bio-fertilizers on growth, yield, quality of China aster (callitephus chinensis) cv. Shashank for cut flower production under agro climatic conditions of Allahabad" was undertaken in The Department of Horticulture, Naini Agriculture institute Sam Higginbottom University of Agriculture Technology and Sciences during winter season of the year 2016-2017. The experiment was laid out in randomized complete block design with 11 treatments replicated thrice. The result revealed that among the different treatments evaluated, $\mathrm{T}_{3}$ performed better when compared to all other treatments with regard to plant height. At 30, 60 and 90 DAT $(19.85,38.70$ and $53.60 \mathrm{~cm})$, the plant height was maximum in $\mathrm{T}_{3}$. There are no significant differences were observed in plant spread at $30 \mathrm{DAT}$, significant differences were noticed at 60 and 90 DAT. The highest plant spread was recorded by $\mathrm{T}_{3}$ with 15.00 and $14.50 \mathrm{~cm}$ at $30 \mathrm{DAT}, 24.00$ and $23.00 \mathrm{~cm}$ at 60 DAT, 43.40 and $42.00 \mathrm{~cm}$ at 90 DAT for both N-S and E-W direction respectively. The lowest plant spread was recorded by $\mathrm{T}_{10}$ with 9.25 and $9.00 \mathrm{~cm}, 18.20$, and 16.20 $\mathrm{cm}, 32.00$ and $31.60 \mathrm{~cm}$ at 30,60 and 90 days DAT for both N-S and E-W direction respectively. Maximum leaf area $\left(7.97 \mathrm{~cm}^{2}, 12.65 \mathrm{~cm}^{2}\right.$, and $18.15 \mathrm{~cm}^{2}$ at 30,60 , and 90 DAT) was noticed in plants received $100 \%$ NPK + Azospirillum + PSB $\left(\mathrm{T}_{3}\right)$. The floral attributes viz., days taken for $1^{\text {st }}$ flowering (65.00days), days taken for 50\% flowering (68.30days), flower stalk $(28.85 \mathrm{~cm})$, flower diameter $(7.80 \mathrm{~cm})$ were higher in the $100 \%$ NPK + Azospirillum + PSB (T3) imposed plants. The yield per hectare was registered higher in the treatment $\mathrm{T}_{6}(7.87$ lakhs/ha) which was closely followed by $\mathrm{T}_{3}$ (7.37 lakhs/ ha) and $\mathrm{T}_{9}(7.03$ lakhs/ha) with regard to post harvest attributes, water uptake, cumulative water uptake, transpiration loss, fresh weight of cut flower, vase life of cut flower was observed. The higher water uptake $(43.00 \mathrm{G}, 45.00 \mathrm{G}, 42.00 \mathrm{G}, 40.00 \mathrm{G}, 38.40 \mathrm{G}, 36.00 \mathrm{G}$, $35.50 \mathrm{G}$ and $34.00 \mathrm{G}$ ) was noticed in the treatment $\mathrm{T}_{3}$. The treatment $\mathrm{T}_{6}$ exhibited significant influence on water loss and recorded least amount of transpiration rate $(43.52 \mathrm{G}, 41.12 \mathrm{G}, 38.62 \mathrm{G}$, $35.00 \mathrm{G}, 34.00 \mathrm{G}, 32.65 \mathrm{G}, 31.20 \mathrm{G}$ and $30.30 \mathrm{G})$ during $1^{\text {st }}$ to $8^{\text {th }}$ days respectively. During the entire period of observations of vase life (viz., $1^{\text {st }}$ to $8^{\text {th }}$ day) the fresh weight of cut flower was found to be maximum in treatment $\mathrm{T}_{6}(88.80 \mathrm{G}, 88.92 \mathrm{G}, 87.60 \mathrm{G}, 86.41 \mathrm{G}, 85.20 \mathrm{G}, 86.23 \mathrm{G}, 85.20 \mathrm{G}$ and $84.12 \mathrm{G}$ respectively. The maximum vase life (8.67 days) was recorded in $\mathrm{T}_{3}$, which was on par with $\mathrm{T}_{6}$ (8.50 days), and $\mathrm{T}_{1}$ (8.40 days) and which were closely followed by $\mathrm{T}_{9}\left(8.00\right.$ days) and $\mathrm{T}_{0}(8.00$ days). Whereas, minimum vase life noticed in $\mathrm{T}_{10}$ (6.42 days). The content of primary nutrients in the plant was significantly influenced by the treatments. Application of bio-fertilizers significantly enhanced nitrogen content in leaves. The treatment $\mathrm{T}_{3}$ recorded higher $\mathrm{N}$ content $(4.22 \%), \mathrm{P}$ content $(0.48 \%)$ and $\mathrm{K}$ content $(2.47 \%)$ respectively. The data on cost economics of China aster cut flower production lay bears that the treatment $\mathrm{T}_{6}$ registered maximum benefit cost ratio of 4.94 and was followed by the treatments $\mathrm{T}_{3}(4.39)$ and $\mathrm{T}_{9}(4.28)$. 


\section{Introduction}

China aster (Callistephus chinensis L. Nees) one of the most popular flowering annuals belongs to the family Asteraceae native of china and was introduced in Europe during 1731 and then spread to different parts of the world (Desai, 1967). It is a hardy and free blooming winter annual, grown all over the world. In India, it is grown traditionally for loose flower, cut flower, vase arrangement, floral decorations, for making garlands and venis for hair decoration, bouquets making, buttonholes, in garden, plants are used as bedding plants, making mixed herbaceous border and as a pot plants. (Kumar et al., 2015; Khangjarakpam et al., 2014; Khanna, et al., 2016).commercial importance of china aster is increasing in Indiaand it is extensively grown in Karnataka, Tamil Nadu, West Bengal, Andra pradesh and Maharashtra by marginal and small farmers (Khangjarakpam et al., 2014).

Among the various factors affecting growth and development of plants, the nutrient management play a vital role. Therefore, attention is needed to apply adequate quality of nutrients through proper nutrient sources (Khanna et al., 2016). Soil nutrient status plays an important role in determining its fertility level. Nitrogen (N), phosphorus (P), potassium $(\mathrm{K})$ and iron $(\mathrm{Fe})$ are key nutrient elements which play a major role in crop production. As majority of the soils in the world are known to be deficient in abovementioned nutrients, there will be a great demand of chemical fertilizers to fulfil nutrients deficiency. According to FAO (2012), by the end of 2016 the global requirement of chemical fertilizers $(\mathrm{N}, \mathrm{P}, \mathrm{K}$ and other macronutrients) is expected to reach 194 million tons. To manufacture this huge quantity of chemical fertilizers large amount of non-renewable resources such as energy in the form of oil and natural gas are required.
Besides, increased cost of fertilizers is also becoming unaffordable by small and marginal farmers.

The fertilizer recommendation for China aster (180:120:60 NPK kg/ha) is very high (Except potassium) which reflects directly on cost of production (Anon, 1991) and also some adverse effect on physical, chemical and biological properties of soil, which is an incoming calamity faced by the agriculturists. Thus,any step leading to reduction of fertilizer doses is a boon to the farmers. Bio-fertilizer when applied to seed, plant surfaces, or soil, colonizes the rhizosphere or the interior of the plant and promotes growth by increasing the supply or availability of primary nutrients to the host plant and also microorganisms in biofertilizers restore the soils natural nutrient cycle and build soil organic matter (Jan and Boswal, 2015). Its application under proper condition increases the yield of various crops by about $25 \%$ and reduces the application of inorganic fertilizers until 25 to $50 \%$ for nitrogen and about $25 \%$ for phosphor nutrient (Aggani, 2013; Ghany et al., 2013; Simarmata, 2013). Moreover, bio-fertilizers can improve soil health and provide protection against drought and some soil borne diseases (Ellafi et al., 2010; Singh and Purohit, 2011).

\section{Materials and Methods}

The present investigation entitled "Effect of NPK and Bio-fertilizers on growth, yield, quality of China aster (callistephus chinensis) cv Shashank for cut flower production under agro climatic conditions of Allahabad" was carried out at Department of Horticulture, Naini Agricultural Institute, Sam Higginbottom University of Agriculture, Technology and Sciences (SHUATS), Allahabad (U.P) in the month of November to March during the winter season of the year 2016-2017. 
The different treatment manipulated as follows T0- RDF + FYM (control), $\mathrm{T}_{1}-100 \%$ NPK + Azospirillum, $\mathrm{T}_{2}-100 \% \mathrm{NPK}+\mathrm{PSB}$, $\mathrm{T}_{3^{-}} 100 \% \mathrm{NPK}+$ Azospirillum $+\mathrm{PSB}, \mathrm{T}_{4^{-}}$ $75 \% \mathrm{~N}$ and $\mathrm{P}+100 \% \mathrm{~K}+$ Azospirillum, $\mathrm{T}_{5}-$ $75 \% \mathrm{~N}$ and $\mathrm{P}+100 \% \mathrm{~K}+\mathrm{PSB}, \mathrm{T}_{6}-75 \% \mathrm{~N}$ and $\mathrm{P}+100 \% \mathrm{~K}+$ Azospirillum $+\mathrm{PSB}, \mathrm{T}_{7^{-}}$ $50 \% \mathrm{~N}$ and $\mathrm{P}+100 \% \mathrm{~K}+$ Azospirillum, $\mathrm{T}_{8^{-}}$ $50 \% \mathrm{~N}$ and $\mathrm{P}+100 \% \mathrm{~K}+\mathrm{PSB}, \mathrm{T}_{9^{-}} 50 \% \mathrm{~N}$ and $\mathrm{P}+100 \% \mathrm{~K}+$ Azospirillum $+\mathrm{PSB}, \mathrm{T}_{10^{-}}$ FYM (15 ton) + Azospirillum + PSB. The treatments were arranged in a randomized block design with 11 treatments in 3 replications.

\section{Results and Discussion}

\section{Growth attributes}

Vegetative parameters viz., plant height, plant spread, number of branches per plant and leaf area were recorded at different stages of plant growth from 30, 60 and 90 days after transplanting and the results from the observations made are as follows.

\section{Plant height (cm)}

There were considerable significant differences found among the treatments, at 90 days after transplanting, where $T_{3}, T_{1}$ and $T_{6}$ recorded the highest plant height of 53.60, 53.50 and 51.72 $\mathrm{cm}$ respectively. The treatment $\mathrm{T}_{9}(48.23 \mathrm{~cm})$ and $\mathrm{T}_{0}(48.00 \mathrm{~cm})$ also recorded higher plant height. The lower plant height was recorded in $\mathrm{T}_{10}(40.00 \mathrm{~cm})$ and $\mathrm{T}_{8}(41.50 \mathrm{~cm})$.

\section{Plant spread (cm)}

There were considerable significant differences found among the treatments with respect to plant spread at 90 days after transplanting, where $\mathrm{T}_{3}$ recorded highest plant spread with $43.40 \& 42.00 \mathrm{~cm}$ for both $\mathrm{N}-\mathrm{S}$ and $\mathrm{E}-\mathrm{W}$ direction respectively which was closely followed by $\mathrm{T}_{1}(41.90 \& 41.00 \mathrm{~cm}), \mathrm{T}_{6}(40.60$ $\& 38.20 \mathrm{~cm})$ and $\mathrm{T}_{9}(39.00 \& 38.00 \mathrm{~cm})$ both
$\mathrm{N}-\mathrm{S}$ and E-W direction respectively. The lowest plant spread was recorded by $\mathrm{T}_{10}$ with $32.00 \& 31.60 \mathrm{~cm}$ for both N-S and E-W direction respectively.

\section{Number of branches per plant}

The treatments $\mathrm{T}_{6}$ (19.17) and $\mathrm{T}_{3}$ (19.00) recorded highest number of branches (18.17) followed by $\mathrm{T}_{1}$ (17.30), $\mathrm{T}_{2}$ (17.17) and $\mathrm{T}_{9}$ (17.00). Whereas the $\mathrm{T}_{10}$ showed the least number of branches (15.50).

\section{Leaf area $\left(\mathrm{cm}^{2}\right)$}

Higher leaf area was recorded by $\mathrm{T}_{3}(18.15$ $\mathrm{cm}^{2}$ ) which was found to be on par with $\mathrm{T}_{1}$ $\left(17.65 \mathrm{~cm}^{2}\right), \mathrm{T}_{6}\left(17.65 \mathrm{~cm}^{2}\right)$ and $\mathrm{T}_{9}\left(17.65 \mathrm{~cm}^{2}\right)$.

$\mathrm{T}_{10}$ recorded lowest leaf area of $9.65 \mathrm{~cm}^{2}$ and $14.65 \mathrm{~cm}^{2}$ at 60 and 90 days after transplanting. However $\mathrm{T}_{8}$ was found to be on par with $\mathrm{T}_{10}$ at 60 and 90 DAT.

\section{Floral attributes}

\section{Days taken for first flowering}

Significant differences in days taken to first flowering were observed due to the treatments imposed (Table 1). Among the 11 treatments, $\mathrm{T}_{3}$ registered the least number of days $(65.00$ days) for first flowering which was on par with $\mathrm{T}_{2}$ (65.40 days), $\mathrm{T}_{1}$ (65.65 days) and $\mathrm{T}_{9}$ (66.00 days). The treatment $\mathrm{T}_{10}$ recorded longer duration for first flowering (75.20 days).

\section{Days taken for $\mathbf{5 0}$ per cent flowering}

Significant differences in days taken to 50 per cent flowering were observed due to the treatments. The number of days taken for 50 per cent flowering varied from 68.30 to 78.00 days (Table 2). Among the 11 treatments, earliest flowering $(50 \%)$ was recorded in the treatment $\mathrm{T}_{3}$ (68.30 days) and the treatments 
$\mathrm{T}_{1}$ (68.75 days), $\mathrm{T}_{9}$ (69.00 days), $\mathrm{T}_{2}(69.30$ days) and $\mathrm{T}_{0}(69.65)$ were on par with $\mathrm{T}_{3}$. The duration taken for 50 per cent flowering was significantly delayed in the treatment $\mathrm{T}_{10}$ (78.00 days) and it was on par by $\mathrm{T}_{8}(76.55$ days).

Table.1 Growth, floral, yield and post-harvest attributes under different treatment conditions

\begin{tabular}{|c|c|c|c|c|c|c|c|}
\hline $\begin{array}{c}\text { Treatment } \\
\text { Symbol }\end{array}$ & Treatments combination & $\begin{array}{r}\text { Plant } \\
\text { height } \\
(\mathrm{cm})\end{array}$ & $\begin{array}{c}\text { Plant } \\
\text { Spread } \\
(\mathbf{c m}) \\
\text { N-S to } \\
\text { E-W }\end{array}$ & $\begin{array}{c}\text { Leaf area } \\
\text { per plant } \\
\left(\mathrm{cm}^{2}\right)\end{array}$ & $\begin{array}{c}\text { Number } \\
\text { of } \\
\text { branches } \\
\text { per plant }\end{array}$ & $\begin{array}{l}\text { Days to 1st } \\
\text { flowering }\end{array}$ & $\begin{array}{l}\text { Days to } \\
50 \% \\
\text { flowering }\end{array}$ \\
\hline $\mathrm{T}_{0}$ & RDF + FYM (Control) & 48.00 & $\begin{array}{l}38.65- \\
37.00\end{array}$ & 17.32 & 18.00 & 66.00 & 69.65 \\
\hline $\mathrm{T}_{1}$ & 100\% NPK + Azospirillum & 53.50 & $\begin{array}{l}41.90- \\
41.00\end{array}$ & 17.65 & 17.30 & 65.65 & 68.75 \\
\hline $\mathrm{T}_{2}$ & $100 \%$ NPK + PSB & 49.23 & $\begin{array}{l}41.00- \\
40.00\end{array}$ & 17.40 & 17.17 & 65.40 & 69.30 \\
\hline $\mathrm{T}_{3}$ & $\begin{array}{l}100 \% \text { NPK + Azospirillum } \\
+ \text { PSB }\end{array}$ & 53.60 & $\begin{array}{l}43.40- \\
42.00\end{array}$ & 18.15 & 19.00 & 71.85 & 68.30 \\
\hline $\mathrm{T}_{4}$ & $\begin{array}{l}75 \% \mathrm{~N} \text { and } \mathrm{P}+100 \% \mathrm{~K}+ \\
\text { Azospirillum }\end{array}$ & 47.53 & $\begin{array}{l}38.00- \\
37.00\end{array}$ & 16.00 & 16.00 & 71.38 & 73.95 \\
\hline $\mathrm{T}_{5}$ & $\begin{array}{l}75 \% \mathrm{~N} \text { and } \mathrm{P}+100 \% \mathrm{~K}+ \\
\text { PSB }\end{array}$ & 47.90 & $\begin{array}{l}35.50- \\
31.90\end{array}$ & 15.80 & 16.20 & 69.75 & 74.65 \\
\hline $\mathrm{T}_{6}$ & $\begin{array}{l}75 \% \mathrm{~N} \text { and } \mathrm{P}+100 \% \mathrm{~K}+ \\
\text { Azospirillum }+\mathrm{PSB}\end{array}$ & 51.72 & $\begin{array}{l}40.60- \\
38.20\end{array}$ & 17.65 & 19.17 & 72.32 & 72.75 \\
\hline $\mathrm{T}_{7}$ & $\begin{array}{l}50 \% \mathrm{~N} \text { and } \mathrm{P}+100 \% \mathrm{~K}+ \\
\text { Azospirillum }\end{array}$ & 46.50 & $\begin{array}{l}36.00- \\
35.00\end{array}$ & 16.40 & 16.27 & 72.00 & 75.65 \\
\hline $\mathrm{T}_{8}$ & $\begin{array}{l}50 \% \mathrm{~N} \text { and } \mathrm{P}+100 \% \mathrm{~K}+ \\
\mathrm{PSB}\end{array}$ & 41.50 & $\begin{array}{l}33.50- \\
31.00\end{array}$ & 15.00 & 16.34 & 66.00 & 76.55 \\
\hline $\mathrm{T}_{9}$ & $\begin{array}{l}50 \% \mathrm{~N} \text { and } \mathrm{P}+100 \% \mathrm{~K}+ \\
\text { Azospirillum }+\mathrm{PSB}\end{array}$ & 48.23 & $\begin{array}{l}39.00- \\
38.00\end{array}$ & 17.65 & 17.00 & 75.20 & 69.00 \\
\hline $\mathrm{T}_{10}$ & $\begin{array}{llll}\text { FYM } \quad(15 & \text { ton }) & + \\
\text { Azospirillum } & & \end{array}$ & 40.00 & $\begin{array}{l}32.00- \\
38.00\end{array}$ & 14.65 & 15.50 & 1.47 & 78.00 \\
\hline & S. Ed. $( \pm)$ & 0.95 & $0.76-0.80$ & 0.39 & 0.37 & 3.07 & 1.77 \\
\hline & C. D. at $5 \%$ & 1.99 & $1.58-1.67$ & 0.80 & 0.78 & & 3.69 \\
\hline
\end{tabular}




\begin{tabular}{|c|c|c|c|c|c|c|c|}
\hline $\begin{array}{c}\text { Treatment } \\
\text { Symbol }\end{array}$ & Treatments combination & $\begin{array}{l}\text { Stalk } \\
\text { length } \\
(\mathrm{cm})\end{array}$ & $\begin{array}{c}\text { Flower } \\
\text { diameter } \\
(\mathrm{cm})\end{array}$ & $\begin{array}{c}\text { Number } \\
\text { of cut } \\
\text { flowers } \\
\text { per plant }\end{array}$ & $\begin{array}{c}\text { Number } \\
\text { of cut } \\
\text { flowers/ } \\
\text { hectare } \\
\text { (lakhs/ha) }\end{array}$ & $\begin{array}{l}\text { Fresh } \\
\text { weight of } \\
\text { cut flower } \\
\text { (G) }\end{array}$ & $\begin{array}{l}\text { Vase life } \\
\text { (days) }\end{array}$ \\
\hline $\mathrm{T}_{0}$ & RDF + FYM (Control) & 25.00 & 6.83 & 5.33 & 5.92 & 76.60 & 8.00 \\
\hline $\mathrm{T}_{1}$ & $100 \%$ NPK + Azospirillum & 28.00 & 7.50 & 6.00 & 6.67 & 79.21 & 8.45 \\
\hline $\mathrm{T}_{2}$ & $100 \%$ NPK + PSB & 26.00 & 7.20 & 5.43 & 6.04 & 78.50 & 8.30 \\
\hline $\mathrm{T}_{3}$ & $\begin{array}{l}100 \% \text { NPK + Azospirillum + } \\
\text { PSB }\end{array}$ & 28.85 & 7.80 & 7.13 & 7.37 & 80.20 & 8.67 \\
\hline $\mathrm{T}_{4}$ & $\begin{array}{l}75 \% \mathrm{~N} \text { and } \mathrm{P}+100 \% \mathrm{~K}+ \\
\text { Azospirillum }\end{array}$ & 25.00 & 6.62 & 5.22 & 5.80 & 80.22 & 7.62 \\
\hline $\mathrm{T}_{5}$ & $75 \% \mathrm{~N}$ and $\mathrm{P}+100 \% \mathrm{~K}+\mathrm{PSB}$ & 23.00 & 6.42 & 5.23 & 5.53 & 80.00 & 7.33 \\
\hline $\mathrm{T}_{6}$ & $\begin{array}{l}75 \% \mathrm{~N} \text { and } \mathrm{P}+100 \% \mathrm{~K}+ \\
\text { Azospirillum }+\mathrm{PSB}\end{array}$ & 28.30 & 7.40 & 7.33 & 7.87 & 84.12 & 8.50 \\
\hline $\mathrm{T}_{7}$ & $\begin{array}{l}50 \% \mathrm{~N} \text { and } \mathrm{P}+100 \% \mathrm{~K}+ \\
\text { Azospirillum }\end{array}$ & 23.00 & 6.30 & 5.33 & 5.49 & 84.15 & 7.00 \\
\hline $\mathrm{T}_{8}$ & $50 \% \mathrm{~N}$ and $\mathrm{P}+100 \% \mathrm{~K}+\mathrm{PSB}$ & 20.52 & 6.15 & 5.00 & 5.44 & 84.12 & 6.55 \\
\hline $\mathrm{T}_{9}$ & $\begin{array}{l}50 \% \mathrm{~N} \text { and } \mathrm{P}+100 \% \mathrm{~K}+ \\
\text { Azospirillum }+\mathrm{PSB}\end{array}$ & 27.87 & 7.10 & 6.88 & 7.03 & 80.16 & 8.00 \\
\hline $\mathrm{T}_{10}$ & FYM (15 ton) + Azospirillum & 20.00 & 5.83 & 3.50 & 4.17 & 80.00 & 6.42 \\
\hline & S. Ed. $( \pm)$ & 0.64 & 0.13 & 0.14 & 0.11 & 1.74 & 0.14 \\
\hline & C. D. at $5 \%$ & 2.35 & 0.28 & 0.29 & 0.23 & 4.95 & 0.40 \\
\hline
\end{tabular}

Flower stalk length $(\mathrm{cm})$

The stalk length ranged from $20.00 \mathrm{~cm}$ to $72.08 \mathrm{~cm}$.

Longest stalk length was recorded in plants receiving treatment $\mathrm{T}_{3}(28.85 \mathrm{~cm})$ and it was on par with $\mathrm{T}_{6}(28.30 \mathrm{~cm}), \mathrm{T}_{1}(28.00 \mathrm{~cm})$ and $\mathrm{T}_{9}(27.87 \mathrm{~cm})$, whereas shortest stalk length was registered in $\mathrm{T}_{10}(22.00 \mathrm{~cm})$ and it was on par with $\mathrm{T}_{8}(20.52 \mathrm{~cm})$.

\section{Flower diameter $(\mathrm{cm})$}

Significant influence of different treatments on Flower diameter was observed. Flower diameter ranged from $5.83 \mathrm{~cm}$ to $7.80 \mathrm{~cm}$ (Table 1). Highest Flower diameter was registered in $\mathrm{T}_{3}(7.80 \mathrm{~cm})$ and it was closely followed by $\mathrm{T}_{1}(7.50 \mathrm{~cm}), \mathrm{T}_{6}(7.40 \mathrm{~cm})$ and $\mathrm{T}_{9}$
$(7.10 \mathrm{~cm})$. The treatment $\mathrm{T}_{10}(5.83)$ recorded lowest flower diameter.

\section{Yield parameters}

\section{Number of cut flowers per plant}

The treatments significantly influenced the number of cut flowers per plant. Among the treatments, highest number of cut flowers per plant was recorded in $T_{6}$ (7.33) which was on par with $\mathrm{T}_{3}$ (7.13) and it was closely followed by $\mathrm{T}_{9}$ (7.03).The lowest number of cut flowers per plant was recorded in $\mathrm{T}_{10}(3.50)$.

\section{Number of cut flowers per hectare (lakhs/ha)}

Treatment differences were significant for number of cut flowers per hectare. Among the 
11 treatments, the highest number of cut flowers per hectare was registered in the treatment $\mathrm{T}_{6} \quad(7.87$ lakhs/ha) which was closely followed by $\mathrm{T}_{3}$ (7.37 lakhs/ha) and $\mathrm{T}_{9}$ (7.03 lakhs/ha). The treatment, $\mathrm{T}_{10}$ recorded lowest number of cut flowers per hectare (4.17 lakhs/ha).

\section{Post-harvest attributes}

\section{Fresh weight of cut flower}

During the entire period of observations on vase life (viz., 1st to $8^{\text {th }}$ day) the fresh weight of cut flower was found to be maximum in treatment, $\mathrm{T}_{6}(88.80 \mathrm{~g}, 88.92 \mathrm{~g}, 87.60 \mathrm{~g}, 86.41$ $\mathrm{g}, 85.20 \mathrm{~g}, 86.23 \mathrm{~g}, 85.20 \mathrm{~g}$ and $84.12 \mathrm{~g}$ respectively) and it was statistically on par with $T_{1}, T_{2} T_{3}$ and $T_{9}$ While the treatment $T_{10}$ recorded minimum fresh weight $(77.52 \mathrm{~g}$, $75.60 \mathrm{~g}, 72.33 \mathrm{~g}, 71.20 \mathrm{~g}, 70.20 \mathrm{~g}, 69.00 \mathrm{~g})$.

\section{Vase life of cut flower}

Application of various dose of fertilizers along with different combinations of biofertilizers at different concentrations produced significant effects on the vase life of China aster cut flowers (Table 1). The maximum vase life (8.67 days) was recorded in $\mathrm{T}_{3}$, which was on par with $\mathrm{T}_{6}$ (8.50 days) and $\mathrm{T}_{1}$ (8.40 days) and which were closely followed by $\mathrm{T}_{9}$ (8.00 days) and T0 (8.00 days. whereas, minimum vase life was noticed in $\mathrm{T}_{10}(6.42$ days).

On the basis of present investigation Thus, it is concluded that the treatments $\mathrm{T}_{6}(75 \% \mathrm{~N}$ and $\mathrm{P}+100 \% \mathrm{~K}+$ Azospirillum $+\mathrm{PSB}$ ) and $\mathrm{T}_{9}(50 \% \mathrm{~N}$ and $\mathrm{P}+100 \% \mathrm{~K}+$ Azospirillum + PSB) was found to be viable treatment combinations which were significantly associated for growth, flowering and quality parameters of China aster. The treatments promoted the rhizosphere colonization Azospirillum and PSB resulting in enhanced nutrient uptake which led to increased growth, yield and quality of China aster cut flowers. The findings of the present field experiments have clearly brought out the positive effects of bio-fertilizers on yield and quality of cut China aster. Besides the treatments were also found to be viable both economically and environmental point of view by reducing the 25 to 50 per cent of inorganic fertilizers.

\section{Acknowledgements}

We authors are greatly thankful to other professors and members, Department of Horticulture for their guidance and support during the research trail and also thankful to Department of Soil science and Department of Agro-meteorology for their information.

\section{References}

Agarwal, S., Agarwal, N., Dixit, A. and Yadav, R. N., 2002. Effect of $\mathrm{N}$ and $\mathrm{K}_{2} \mathrm{O}$ on African marigold in Chhattisgarh region. J. Orn. Hort., 5 (1): 86-87.

Aggani S L. 2013. Development of biofertilizers and its future perspective. Sch Acad J

Ajay, C. and Vijai, K., 2007. Effect of graded levels of nitrogen and VAM on growth and flowering in Calendula (Calendula officinalis Linn). J. Orn. Hort., 10 (1): 61-63.

Bhattacharjee, R. and Dey, U., 2014. Biofertilizer, a way towards organic agriculture: A review. African Journal of Microbiology Research, 8(24), pp.2332-2343.

Chaudhari, C. K., Jadav, R. G. and Masu, M. M., 2009. Effect of bio-fertilizers and their combination with nitrogen fertilizer on growth, yield and quality of rose (Rosa damascena L.). The Asian J. Hort., 4 (2): 373-376.

Copper R 1979. Bacterial fertilizers in the 
Soviet Unions. Soil Fert 22: 327-33.

Desai, B. L., 1967. Seasonal flowers, ICAR publications, New Delhi, Pp. 53-56.

Khanna, P. R., Bohra, M., Punetha, P. and Nautiyal, B., 2016. Studies on the effect of organic manures and PSB on vegetative and floral parameters of China aster (Callistephus chinensis Allistephus chinensis Allistephus chinensis (L.) Ness.) CV. Kamini under mid Amini under mid hills region of Himala hills region of Himalaya.

Kumar, A. V. and Natarajan, N., 2006, Nutrient management and flower position on seed quality in marigold. Adv. Plt. Sci., 19 (1): 3740.

Kumar, M. V. N. and Kumar, S. S., 2000.
Studies on character association and path coefficients for grain yield and oil content in maize (Zea mays L.).Annals of Agricultural Research, 21(1), pp.7378.

Mehdipour Moghadam, M. J., Emtiazi, G. and Salehi, Z., 2012. Enhanced auxin production by Azospirillum pure cultures from plant root exudates. Journal of Agricultural Science and Technology, 14(5), pp.985-994.

Meshram, N., Badge, S., Bhongle, S. A. AND Khiratkar, S. D., 2008. Effect of bioinoculants with graded doses of NPK on flowering, yield attributes and economics of annual chrysanthemum. $J$. Soils Crops, 18 (1): 217-220.

\section{How to cite this article:}

Sowmya, K.A. and Prasad, V.M. 2017. Effect of NPK and Bio-Fertilizers on Growth, Yield, Quality of China Aster (Callistephus chinensis) cv. Shashank for Cut Flower Production under Agro Climatic Conditions of Allahabad. Int.J.Curr.Microbiol.App.Sci. 6(10): 3204-3210. doi: https://doi.org/10.20546/ijcmas.2017.610.375 